\author{
G. Paskalov ${ }^{1,2 *}$, R. Jarvis ${ }^{2}$, L. Adjarova ${ }^{3}$, \\ E. Benova ${ }^{4}$ (D), and B. Harmison ${ }^{2}$ \\ ${ }^{1}$ Plasma Microsystems LLC, USA, Los Angeles, \\ ${ }^{2}$ ELXUS, LLC, Oak Hill, USA, Virginia \\ ${ }^{3}$ Energy Agency of Plovdiv, Bulgaria, Plovdiv \\ ${ }^{4}$ Sofia University "St. KlimentOhridski, Bulgaria, Sofia \\ *e-mail: george.paskal44@gmail.com
}

\title{
POROUS MATERIAL INTERACTIONS WITH RF PLASMA
}

The impact of plasma on the material is carried out as a result of a number of complexes, interrelated processes of energy, mass and charge exchange of plasma particles with the substrate. The result of such interactions are desorption of atoms and molecules from substrate, sputtering and evaporation of the particulate material, structure and phase state changes. During the plasma treatment, materials interact with active and inactive plasma particles, having high kinetic or potential energy. There are physical and chemical interaction of particles. Physical interaction of the particles is mostly by kinetic energy, which can exceed the heat by several orders of magnitude. The charged particles also have a high potential energy - the energy of recombination. In this regard, the particles upon collision with a physically solid material can spray the solid material.

The paper presents the study of low-temperature surface modification interactions with a porous material. These are low energy sources of induction and capacitive radio-frequency discharges at a pressure of $0.1-2$ torr, are used. The objects of research are the useful creation of modified carbon sorbents.

Key words: low pressure discharge, surface modification.

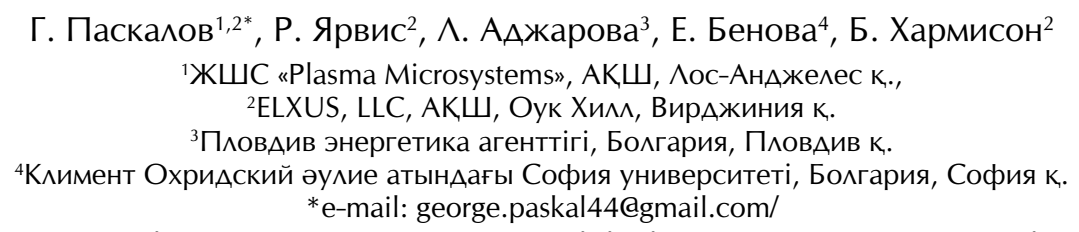

Кеуекті материалдың жоғары жиікікті плазмамен әрекеттесуі

Плазманың материалға әсері энергия, масса және бөлшектерін төсеммен қайта зарядтау бірқатар кешенді өзара байланысты процестерінің нәтижесінде жүзеге асырылады. Мұндай өзара әрекеттесудің нәтижесі атомдар мен молекулалардың төсемнен десорбция процесі, шашырау және бөлшектер түрінде материалдың булануы, сондай-ақ оның құрылымы мен фазалық күйінің өзгеруі болып табылады. Плазмалық өңдеу кезінде материалдар жоғары кинетикалық немесе потенциалдық энергиясы бар белсенді және белсенді емес плазмалық бөлшектермен әрекеттесетіні белгілі. Бөлшектердің арасында физикалық және химиялық әрекеттесулер болатыны көп зерттеулермен дәлелденген және айқын. Негізінен физикалық өзара әрекеттесу кинетикалық энергияның әсерінен болады, сондықтан ол жылу энергиясының көлемінен бірнеше рет асып түседі. Зарядталған бөлшектер жоғары потенциалдық энергиясына ие екені белгілі, мұны рекомбинация энергиясы деп атайды. Осыған байланысты бөлшектер физикалық қатты материалмен соқтығысқанда қатты материалды шашыратуы мүмкін.

Бұл ұсынылған мақалада біз кеуекті материалмен төмен температуралық модификациялық, әрекеттесуді зерттеу нәтижелерін келтірдік. 0,1 - 2 торр қысымындағы индуктивті және сыйымды радиожиілік разрядтарының төмен энергия көздері қолданылады. Зерттеу нысаны болып өзгертілген көміртегі сорбенттерінің түзілуі табылады.

Түйін сөздер: төмен қысымды разряд, беттік модификация. 


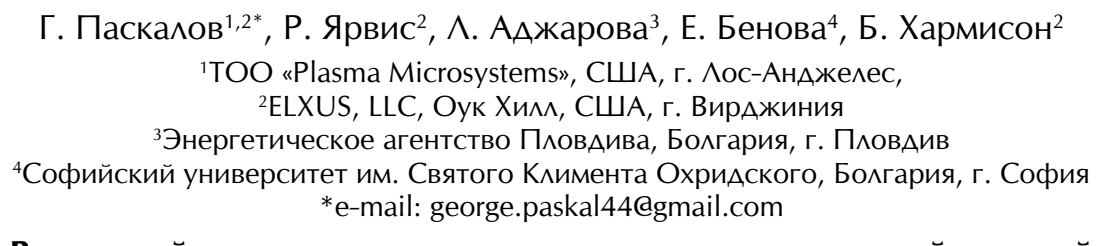

Взаимодействие пористого материала с высокочастотной пмазмой

\begin{abstract}
Воздействие плазмы на материал осуществляется в результате ряда комплексов, взаимосвязанных процессов энерго-, массо- и перезарядки частиц плазмы с подложкой. Результатом таких взаимодействий является десорбция атомов и молекул с поАложки, распыление и испарение материала в виде частиц, а также изменение структуры и фазового состояния. Во время плазменной обработки материалы взаимодействуют с активными и неактивными частицами плазмы, имеющими высокую кинетическую или потенциальную энергию. Аоказано, что существуют физическое и химическое взаимодействие частиц, гАе при этом физическое взаимодействие частиц происходит, в основном, за счёт кинетической энергии, которая может на несколько порядков превышать тепловую энергию. Заряженные частицы также обладают высокой потенциальной энергией, так называемой энергией рекомбинации. В связи с этим частицы при столкновении с физически твёрдым материалом могут распылять твёрдый материал. В данной статье представлены результаты исследования низкотемпературных модификационных взаимодействий с пористым материалом. Используются малоэнергетические источники индукционных и ёмкостных радиочастотных разрядов при Аавлении 0,1 - 2 торр. Объектами исследований являются образования модифицированных углеродных сорбентов.
\end{abstract}

Ккючевые слова: разряд низкого Аавления, модификация поверхности.

\section{Introduction}

This paper is focused on the changes of the properties of solid materials with porous structures after their interaction with the low-pressure plasma. As the object of study is carbonaceous sorbents made from agricultural waste [1-2] and designed by the authors for several advantageous uses. The surface modification capabilities range from differently charged carbon to additive chemistries for specific adsorbent applications.

\section{Research methods}

In the first stage of research RF discharge plasma surface activation is performed on carbonaceous sorbents. The sorbent matrix is based on carbon and silicon compound (C-Si) or carbon and potassium (C-K) and represent the longitudinal size of the granules 2 - 7 $\mathrm{mm}$ and a thickness of $1 \mathrm{~mm}$. The matrix of the sorbent is treated in the different zones of plasma discharge. In case of ICP (inductively coupled plasma) the matrix passed through the discharge zone or introduced into the plasma jet. In the case of capacitive discharge, matrix is processed in a rotating drum, or in the interelectrode space (between flat electrodes). Also, the potential exists to have a 'free space' processing vessel.

\section{Research background}

The impact of plasma on the material is carried out as a result of a number of complexes, interrelated processes of energy, mass and charge exchange of plasma particles with the substrate. The result of such interactions are desorption of atoms and molecules from substrate, sputtering and evaporation of the particulate material, structure and phase state changes. During the plasma treatment, materials interact with active and inactive plasma particles, having high kinetic or potential energy. There are physical and chemical interaction of particles. Physical interaction of the particles is mostly by kinetic energy, which can exceed the heat by several orders of magnitude. The charged particles also have a high potential energy - the energy of recombination. In this regard, the particles upon collision with a physically solid material can spray the solid material.

The chemical reaction of the active particles is due to a high potential energy defined by the presence of unsaturated chemical bonds. The interaction of these particles with the treated material leads to the formation of chemical compounds. During plasma processing it is impossible to separate the physical and chemical interactions and specify any one process that is responsible for the effect of exposure to the plasma. Each process depends on each other. The result of processing is usually caused by simultaneous action on the material and it is determined by various factors and parameters generated by the reaction energy potential. Depending on the properties of material and lowtemperature plasma parameters, the main mechanism of interaction and type of charged particles are 
contributing the most significant contribution to surface modification. Selection of induction and capacitive discharges allow to compare the influence on the sorbent characteristics (grain size, the volume of pores, etc.) at different operating conditions: energy of ions and electrons, concentration, heat flux, etc. ICP discharge has a higher gas temperature compared with CCP discharge, which generate non - equilibrium plasma, i.e the electron temperature is higher than ion temperature. After the plasma exposure, we analyze particle size distribution (laser granulometry), the structure of the volume of material based on an organic compound with the definition of the characteristics of the bulk structure (high resolution X-ray microtomography), the elemental composition (X-ray fluorescence spectroscopy), the surface morphology of the particles of the sorbent (scanning electron microscopy), and characteristics of the surface wettability with the definition of potential adsorption (scanning electron microscopy in the natural environment mode ESEM) and with ASTM equivalent molecule adsorption testing with iodine. Comparison matrix characteristics before and after the plasma treatment allows to define and optimized plasma treatment process based on maximum surface activation.

\section{Experiments and discussion of the results}

Experiments were performed in the RF power range of $0.1-3.0 \mathrm{~kW}$ (discharge power of $0.1-1.5$ $\mathrm{kW})$. The pressure in the reactor of below 2.0 Torr, plasma processing gas - Argon at suitable flow rate for the reaction chamber [3]. Variation of external parameters of inductive and capacitive discharges, various treatment zones allowed to create plasma conditions in a wide range: the concentration of charged particles $10^{11}-10^{13} \mathrm{~cm}^{-3}$, the ion energy between 10 and $60 \mathrm{eV}$, the electric field strength of $500 \mathrm{~V} / \mathrm{m}$. A significant difference between electron temperature and gas temperature within the investigated pressure range allowed to get the positive effects of plasma surface modification at temperatures ranging from room temperature up to $130-170^{\circ} \mathrm{C}$. This is an optimal processing range for sorbent's matrix. Modification of the surface of the sorbents leads to an opening of the meso space structures (Fig.1).

Activation of the surface, which will increase the sorption capacity for hydrocarbon products. Treatment of sorbent matrix type $\mathrm{C}-\mathrm{K}$ at reduced pressure show significant re-distribution of average pore size: middle (meso) size pores are transferred to some large ones and the appearance of consider- able amounts of small pore size (Fig.2). The minimum pore size is reduced to $3 \mu \mathrm{m}$, the maximum rose to 33 microns.

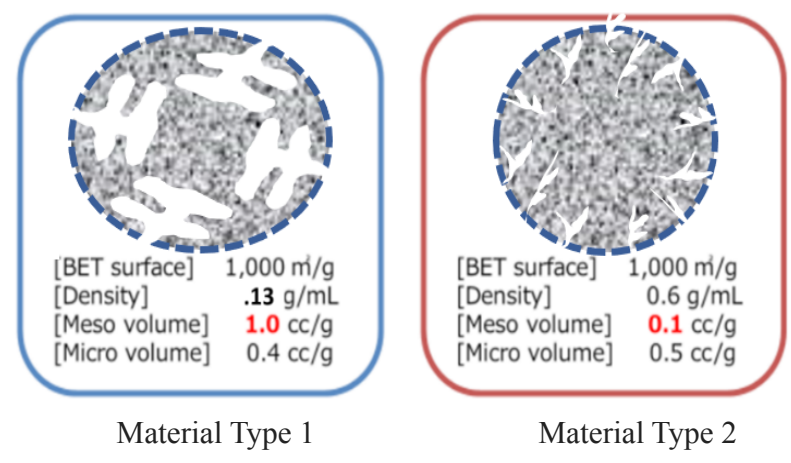

Figure 1 - Modification of the surface of the sorbents

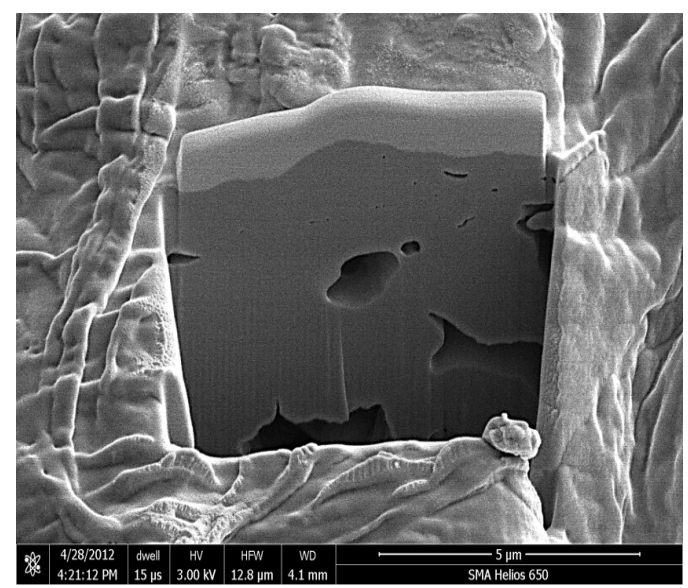

Figure 2 - The microstructure of the matrix after plasma treatment.

Gravimetric studies show increasing sorption capacity of the sorbent at $15-17 \%$. This is collaborated by hydrocarbon sorbency testing, as shown in Figure 3 for commercial motor oil as based upon ASTM F726. The subject materials are 3 types, a commercial sorbent available at any retail outlet, the Type 2 as shown in Figure 1, and the Type 1 also shown in Figure 1. The Type 1 has been treated in 3 different ways, first, a crushing of the granular) to exemplify the importance of the larger spaces (like meso spaces) in the collection and holding power for hydrocarbons. Then the modified Type 1 to indicate that processing differences can create enhanced benefits; modified and max modified.

Plasma treatment of matrix based on C-Si leads to similar results for the chem-adsorption. The 
difference in this case are only the parameters for the small and large pore size. The minimum pore size for the $\mathrm{C}$-Si matrix after exposure to plasma is 17 microns, the maximum - 73 microns. The effectiveness of the surface activation is confirmed by the results from impregnation of the matrix [4]. At the same time coating on the activated surface or to introduce (impregnate) different substances into the matrix allow to obtain the new sorbents selective properties. Plasma modified matrix allow to attach to the surface or into the pores of the matrix various elements, for example phosphorus (Fig. 4). Thus, it is possible to change the composition and properties of the matrix and dramatically increase the sorption properties for different and specific elements from solution (Table 1). Experiments showed that sorption capacity is about $8.1 \mathrm{mg} / \mathrm{g}$, and specifically for Vanadium is about $4.8 \mathrm{mg} / \mathrm{g}$.

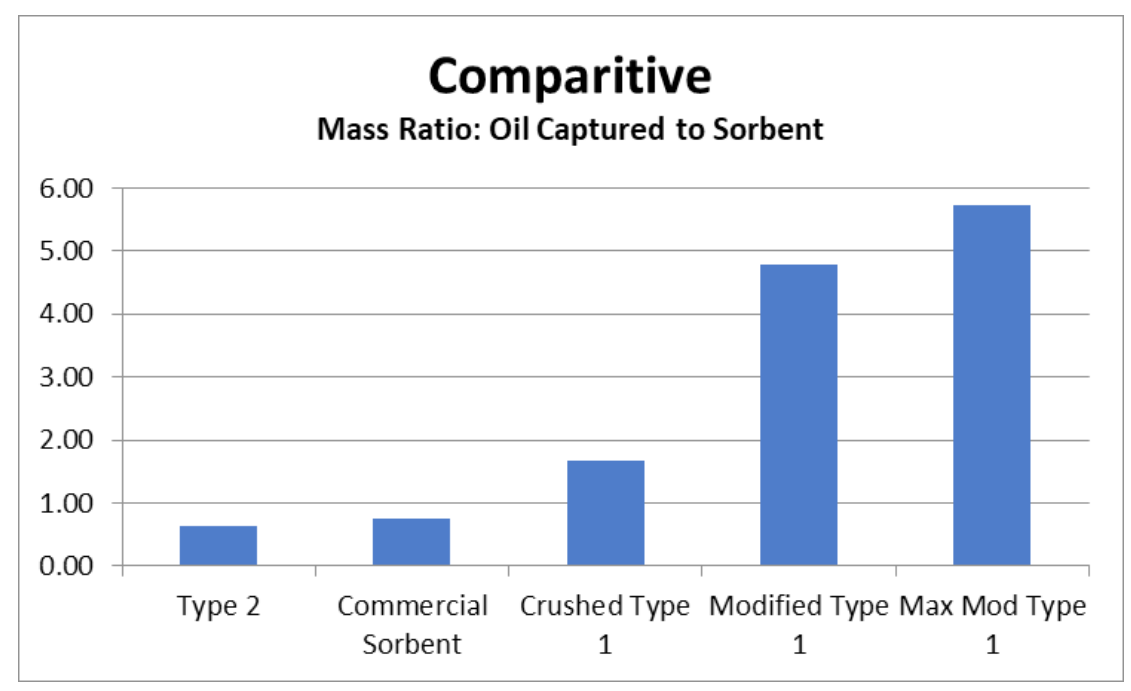

Figure 3 - Sorption capacity of the sorbent

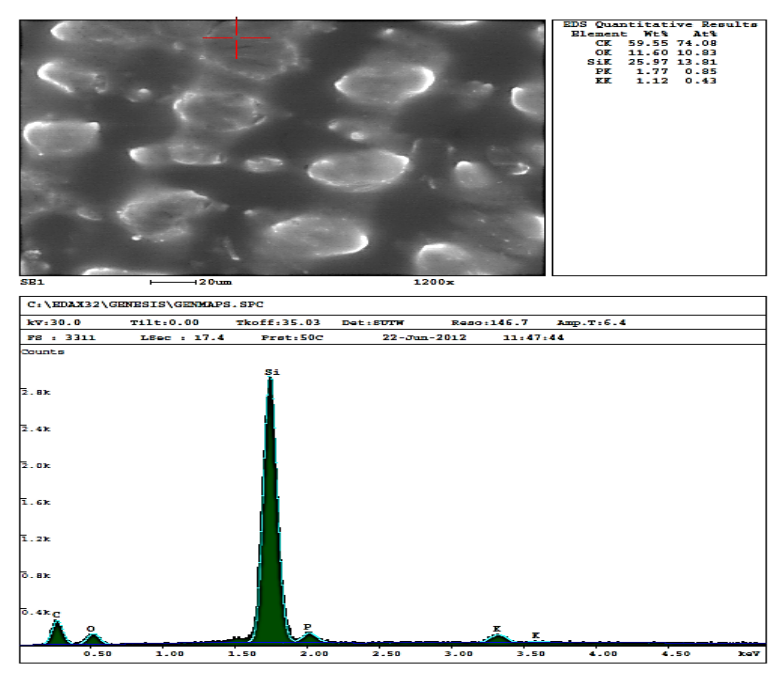

a

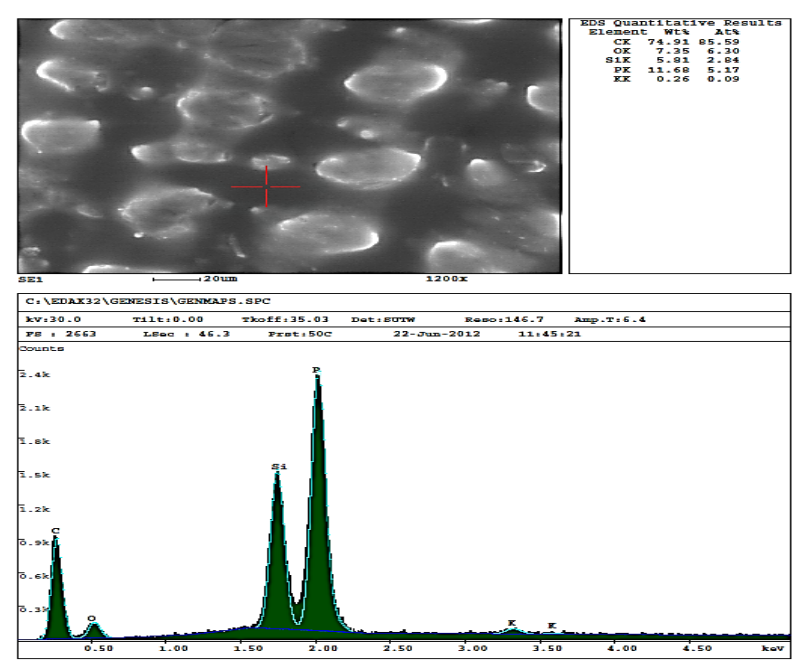

b

a) the composition of the matrix before impregnation, b) the composition of the matrix after impregnation

Figure 4 - The result of impregnation of phosphorus on the surface of the treated plasma sorbent matrix: 
In another implementation, impregnation of the sorbent matrix type $\mathrm{C}$-Si by nano-powder $\left(\mathrm{SiO}_{2}\right.$ particle size between 20 and $50 \mathrm{~nm}$ ) was performed. The presence of silicon in the lattice of the matrix, adding Silicon Oxide powder to the surface of the matrix and into pores, generate a stable structure of homogeneous $\mathrm{Si}$ based materials. In case of bio-sorbents, different microorganisms are used and tested. The mechanism of impregnation on the surface and in the bulk material, is almost similar.

Table 1 - Reduction of the impurities after cleaning the solution by activated sorbent

\begin{tabular}{|c|c|c|c|c|c|c|c|c|}
\hline Element & $\mathrm{Mn}$ & $\mathrm{Ni}$ & $\mathrm{W}$ & $\mathrm{In}$ & $\mathrm{Cu}$ & $\mathrm{Cr}$ & $\mathrm{Mb}$ & $\mathrm{Re}$ \\
\hline$\%$ Reduction & 9 & 24 & 35 & 40 & 62 & 62 & 72 & 90 \\
\hline Hydrocarbon & $\mathrm{ETB}$ & $\mathrm{TOL}$ & $\mathrm{XY} 1$ & $\mathrm{BEN}$ & & & & \\
\hline$\%$ Reduction & 67 & 30 & 62 & 78 & & & & \\
\hline
\end{tabular}

[ETB - Ethylbenzene; TOL - Toluene ; XYL - Xylene ; BEN - Benzene]

Formation of different phases, which have their own characteristics that determine the nature of the processes. Surface phases appear in many surface phenomena. Therefore, the choice of sorbent surface as the object of the plasma exposure gives an extensive information about the processes occurring with a porous structure in the plasma.

\section{Conclusions}

1. Response of changes in the properties of porous surfaces of the body, its inter-porous and surface space from the impact of low-temperature plasma stream with specific parameters allows for the implementation and use for physical and chemical processes utilizing the same subject material, and to develop a physical model of plasma interaction with a porous structure.

2. Modification by thermal plasma or plasmachemical methods allows to add to the surface and into the pore space of the matrix various reagents and thus change the composition and properties of the matrix and increase the sorption properties and specific selection of different element extraction from solutions.

3. Low temperature RF plasma at pressures of $0.1-2.0$ Torr can be successfully used to solve various environmental problems.

\section{References}

1 Gafarov I., Paskalov G., Ibragimov M. and Musharatskiy L. Universal Sorbent Produced from Agricultural Waste for Purification //International Symposium "Environmental and Engineering Aspects for Living", 7-28 November 2014, Hannover. - P. 57-58.

2 Shaihiev I., Galblaub O., Stepanova S. and Timirbaeva G. Oil spill cleanup of water surface by plant-based sorbents: Russian practices. //Process Safety and Environmental Protection. - 2016. - Vol. 101. - P. 88-92.

3 Gafarov I., Abdullin I., Ibragimov R., Paroshin V. and O.V. Zaitseva. Modification Sorbents of High-frequency Capacitive Plasma of Low Pressure $/ 5^{\text {th }}$ Central European Symposium on Plasma Chemistry. - Balatonalmadi, Hungary, 25-29 August 2013. - P.109.

4 Gafarov I., Paskalov G. and Abdullin I. Surface Activation of Sorbents by Using RF Plasma at Reduced Pressure/ I //9 ${ }^{\text {th }}$ International Conference on Plasma Assisted Technologies//ICPAT-9, 23-26 June, 2014, St.-Petersburg, Russia. - 2014. - P.54-57.

\section{References}

1. I. Gafarov, G. Paskalov, M. Ibragimov, and L.Musharatskiy, Universal Sorbent Produced from Agricultural Waste for Purification, International Symposium "Environmental and Engineering Aspects for Living", 7-28 November 2014, Hannover, p. 57-58 (2014).

2. I. Shaihiev, O. Galblaub, S. Stepanova, and G. Timirbaeva, Process Safety and Environmental Protection, 101, 88-92 (2016).

3. I. Gafarov, I. Abdullin, R. Ibragimov, V. Paroshin, and O.V. Zaitseva, Modification Sorbents of High-frequency Capacitive Plasma of Low Pressure, $5^{\text {th }}$ Central European Symposium on Plasma Chemistry, Balatonalmadi, Hungary, 25-29 August 2013, p.109 (2013).

4. I. Gafarov, G. Paskalov, and I. Abdullin, Surface Activation of Sorbents by Using RF Plasma at Reduced Pressure, I, $9^{\text {th }}$ International Conference on Plasma Assisted Technologies, ICPAT-9, 23-26 June, 2014, St.-Petersburg, Russia, pp.54-57 (2014). 